\title{
Task 4.4 - Development of Supercritical Fluid Extraction Methods for the Quantitation of Sulfur Forms in Coal
}

\author{
Topical Report \\ April 1995 \\ RECEIVED \\ AUG 151997 \\ By \\ Ronald C. Timpe \\ OSTI
}

Work Performed Under Contract No.: DE-FC21-93MC30097

For

U.S. Department of Energy

Office of Fossil Energy

Federal Energy Technology Center

Morgantown Site

P.O. Box 880

Morgantown, West Virginia 26507-0880

By

Energy \& Environmental Research Center

University of North Dakota

P. O. Box 9018

Grand Forks, North Dakota 58202-9018 


\section{Disclaimer}

This report was prepared as an account of work sponsored by an agency of the United States Government. Neither the United States Government nor any agency thereof, nor any of their employees, makes any warranty, express or implied, or assumes any legal liability or responsibility for the accuracy, completeness, or usefulness of any information, apparatus, product, or process disclosed, or represents that its use would not infringe privately owned rights. Reference herein to any specific commercial product, process, or service by trade name, trademark, manufacturer, or otherwise does not necessarily constitute or imply its endorsement, recommendation, or favoring by the United States Government or any agency thereof. The views and opinions of authors expressed herein do not necessarily state or reflect those of the United States Government or any agency thereof. 


\section{DISCLAIMER}

Portions of this document may be illegible electronic image products. Images are produced from the best available original document. 


\section{DISCLAMMIR}

This final report was prepared as an account of work sponsored by an agency of the United States Government. Neither the United States Government, nor any agency thereof, nor any of their employees makes any warranty, express or implied, or assumes any legal liability or responsibility for the accuracy, completeness, or usefulness of any information, apparatus, product, or process disclosed or represents that its use would not infringe privately owned rights. Reference herein to any specific commercial product, process, or service by trade name, trademark, manufacturer, or otherwise does not necessarily constitute or imply its endorsement, recommendation, or favoring by the United States Government or any agency thereof. The views and opinions of authors expressed herein do not necessarily state or reflect those of the United States Government or any agency thereof.

\section{ACKNOWLEDGMIENT}

This final topical report was prepared with the support of the U.S. Department of Energy (DOE), Morgantown Energy Technology Center, Cooperative Agreement No. DE-FC2193MC30097. However, any opinions, findings, conclusions, or recommendations expressed herein are those of the author(s) and do not necessarily reflect the views of the DOE.

\section{EERC DISCLAMMER}

LEGAL NOTICE This research report was prepared by the Energy \& Environmental Research Center (EERC), an agency of the University of North Dakota, as an account of work sponsored by U.S. Department of Energy. Because of the research nature of the work performed, neither the EERC nor any of its employees makes any warranty, express or implied, or assumes any legal liability or responsibility for the accuracy, completeness, or usefulness of any information, apparatus, product, or process disclosed, or represents that its use would not infringe privately owned rights. Reference herein to any specific commercial product, process, or service by trade name, trademark, manufacturer, or otherwise does not necessarily constitute or imply its endorsement or recommendation by the EERC. 
LIST OF FIGURES $\ldots \ldots \ldots \ldots \ldots \ldots \ldots \ldots \ldots \ldots \ldots \ldots \ldots \ldots \ldots \ldots$

LIST OF TABLES $\ldots \ldots \ldots \ldots \ldots \ldots \ldots \ldots \ldots \ldots \ldots \ldots \ldots \ldots \ldots$

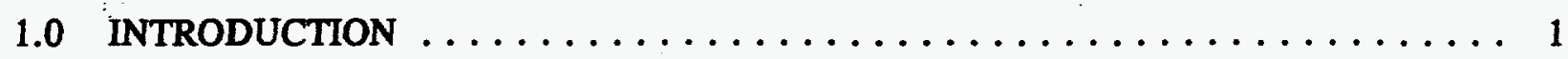

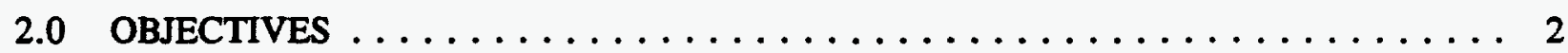

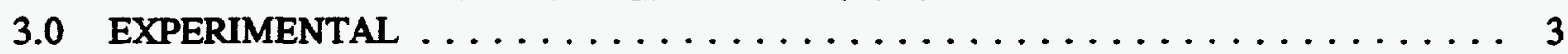

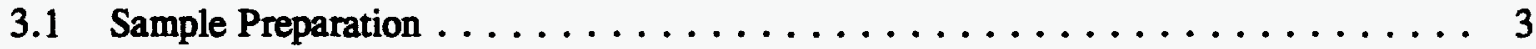

3.2 Super- and Subcritical Fluid Extractions Under Pyrolysis Conditions . . . . . . . . . . 4

3.3 Evaluation of Mass Balance and Selectivity of ASTM D2492 and of SFE and

Pyrolysis-SFE ........................ 4

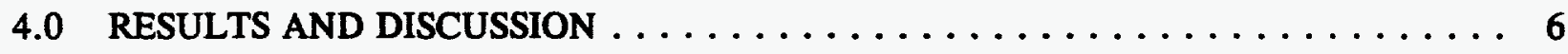

4.1 Supercritical $\mathrm{CO}_{2}$ Extractions of Elemental S Under Mild Conditions $\ldots \ldots \ldots$

4.2 Nonaqueous Extractions of Sulfatic, Pyritic and Easy Organic $S$ under Conditions

of Increasing Severity . . . . . . . . . . . . . . . . . . . 6

4.3 Extraction of Sulfatic, Pyritic and Easy Organic S with Supercritical Water . . . . 10

4.4 Comparison of Sub- and Supercritical $\mathrm{H}_{2} \mathrm{O}$ and with $\mathrm{CO}_{2} / 10 \%$ Methanol

Extraction . . . . . . . . . . . . . . . . . . . . . . 10

4.5 Selective Extraction of Sulfatic Sulfur and Evaluation of Mass Balance . . . . . . 15

$4.6{ }^{34} \mathrm{~S} /{ }^{32} \mathrm{~S}$ Ratios of Sulfur Forms Extracted from Bituminous Coals . . . . . . . . . . 16

4.7 Proposed Method for Selective Extraction and Determination of Sulfur Forms

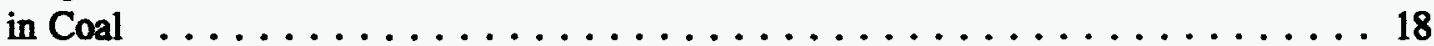

4.8 Additional Information Regarding This Study $\ldots \ldots \ldots \ldots \ldots \ldots \ldots \ldots$

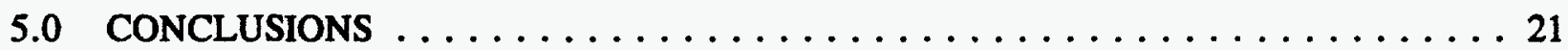

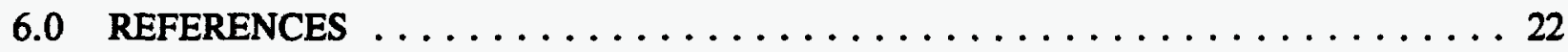

7.0 PUBLICATIONS AND PRESENTATIONS REPORTING RESULTS FROM

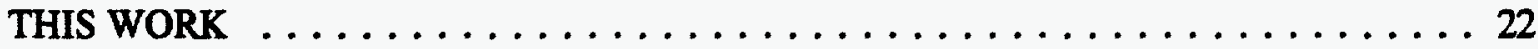




\section{LIST OF FIGURES}

1 Total ion chromatogram of extract obtained by pyrolysis-SFE-GC-MS on-line

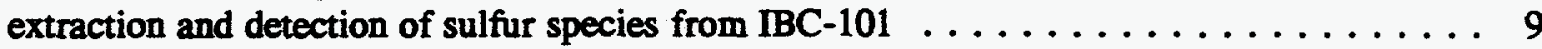

2 GC-AED chromatogram showing sulfur from various species contained in extract

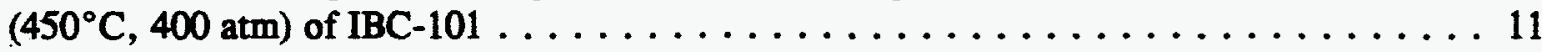

3 GC-AED chromatogram showing carbon from various species contained in extract

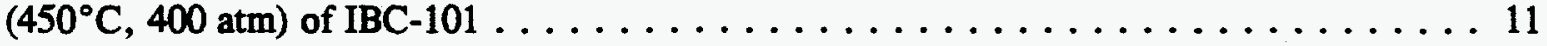

4 GC-AED chromatogram showing sulfur from various species contained in extract $\left(450^{\circ} \mathrm{C}, 400 \mathrm{~atm}\right)$ of IBC-107 .

5 GC-AED chromatogram showing carbon from various species contained in extract $\left(450^{\circ} \mathrm{C}, 400 \mathrm{~atm}\right)$ of IBC- 107

6 Schematic of extraction techniques for removing sulfur forms from bituminous coals and the analysis techniques used to characterize the extracts and residue $\ldots \ldots \ldots \ldots$ 


\section{LIST OF TABLES}

1 Proximate and Total Sulfur Analysis of Coal Samples $\ldots \ldots \ldots \ldots \ldots$

2 Sulfur Form Analysis of Coal Samples . . . . . . . . . . . . . . . . . 4

3 Percentage of Sulfur Removal from Elemental Sulfur-Free IBC-101 and Indiana No. 3 with Various Supercritical Fluids $\ldots \ldots \ldots \ldots \ldots \ldots \ldots \ldots \ldots \ldots \ldots$

4 Pyrolysis-SFE Sulfur Removal from IBC-101 and Indiana No. 3 Using Supercritical $\mathrm{CO}_{2} / 10 \%$ Methanol and $\mathrm{CO}_{2}$ /Phosphoric Acid $\ldots \ldots \ldots \ldots \ldots$

5 Proximate Analysis of Untreated, SFE-, $\mathrm{HCl}$ - and Formic Acid-Treated IBC-101

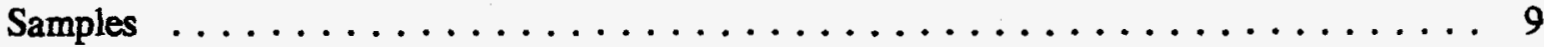

6 Extraction of Sulfur from Coal (IBC-101) with Supercritical Water . . . . . . . . . . . . 10

7 Sulfur Removal from IBC-101 and IBC-107 Coals with $\mathrm{CO}_{2} / 10 \%$ Methanol at

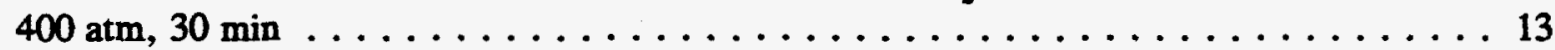

8 Sulfur Removal from Coals IBC-101 and IBC-107 with Water at $400 \mathrm{~atm}, 30 \mathrm{~min} \ldots 13$

9 Removal of Sulfur under Sub- and Supercritical Water Extraction Conditions . . . . . . . 14

10 Stable Sulfur Isotope Data of Sulfate Sulfur Obtained under Different Extraction

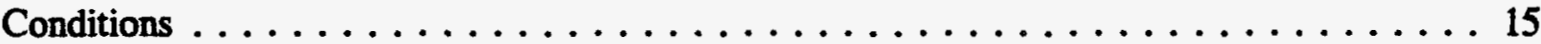

11 Sulfur Isotopic Composition of Fractions Obtained from IBC-107 . . . . . . . . . . 17

12 Stable Sulfur Isotope Ratios for Five Bituminous Coals $\ldots \ldots \ldots \ldots \ldots$ 


\section{TASK 4.0 - DEVELOPMENT OF SUPERCRITICAL FLUID EXTRACTION METHODS FOR THE QUANTITATION OF SULFUR FORMS IN COAL}

\subsection{INTRODUCTION}

Development of advanced fuel forms depends on having reliable quantitative methods for their analysis. Determination of the true chemical forms of sulfur in coal is necessary to develop more effective methods to reduce sulfur content. Past work at the Energy \& Environmental Research Center (EERC) indicates that sulfur chemistry has broad implications in combustion, gasification, pyrolysis, liquefaction, and coal-cleaning processes.

Current analytical methods are inadequate for accurately measuring sulfur forms in coal. This task was concerned with developing methods to quantitate and identify major sulfur forms in coal based on direct measurement (as opposed to present techniques based on indirect measurement and difference values). The focus was on the forms that were least understood and for which the analytical methods have been the poorest, i.e., organic and elemental sulfur. Improved measurement techniques for sulfatic and pyritic sulfur also need to be developed. A secondary goal was to understand the interconversion of sulfur forms in coal during thermal processing.

EERC has developed the first reliable analytical method for extracting and quantitating elemental sulfur from coal (1). This method has demonstrated that elemental sulfur can account for very little or as much as one-third of the so-called organic sulfur fraction. This method has disproved the generally accepted idea that elemental sulfur is associated with the organic fraction. A paper reporting the results obtained on this subject entitled "Determination of Elemental Sulfur in Coal by Supercritical Fluid Extraction and Gas Chromatography with Atomic Emission Detection" was published in Fuel (A).

Standard American Society for Testing and Materials (ASTM) sulfur forms analyses (ASTM D2492) have not previously been evaluated on a mass-balance basis (2). We have shown that standard $\mathrm{HCl}$ extraction (for sulfate) gives poor sulfur mass balance, and an improvement using formic acid has been developed (3). A paper reporting the results obtained on this subject, entitled "An Improved Method for Extracting Sulfate from Bituminous Coals Using Formic Acid," was accepted for publication in Fuel (B). Standard $\mathrm{HNO}_{3}$ extraction (for pyritic S) has also been shown to give a subquantitative mass balance. In addition, we have shown that $\mathrm{HNO}_{3}$ radically changes the chemical structure of the coal (making subsequent forms analyses suspect). The common method (ASTM D2492) of measuring iron to determine pyritic sulfur was also shown to be questionable since the stoichiometry of iron-sulfur compounds may not always be that of pyrite. We have shown that chromous acid extraction gives improved mass balance and less disruption of the coal matrix than $\mathrm{HNO}_{3}$ for determining pyritic sulfur in coal.

Two approaches have been developed at EERC that show great potential to extract coal sulfur forms with sufficient selectivity to provide accurate form data. Breliminary interpretations of these extraction data were thought to indicate, first, that supercritical $\mathrm{CO}_{2} / 10 \%$ methanol under pyrolysis conditions $\left(450^{\circ} \mathrm{C}\right)$ selectively extracts true organic sulfur but not sulfatic or pyritic sulfur (note that these extractions are performed on samples that have previously been extracted using our supercritical 
analysis. Two papers published in Fuel, entitled "Sulfur Removal from Coal by Analytical-Scale Supercritical Fluid Extraction (SFE) under Pyrolysis Conditions" (C) and "The Use of Stable Sulfur Isotope Ratio Analysis to Assess Selectivity of Chemical Analyses and Extractions of Forms of Sulfur in Coal" (D), document the results of these experiments.

Second, $\mathrm{CO}_{2} / \mathrm{H}_{3} \mathrm{PO}_{4}$ appeared to remove $80 \%$ of the total sulfur, including sulfatic, pyritic, and what can be referred to as "easy" organic sulfur. Extraction methods used in attempts to remove sulfur, including the remaining $20 \%$, have proven to be either ineffective, or, in the case of peroxidation or molten caustic leaching, lack economic and/or technical feasibility. This so-called "hard" organic sulfur appears to be immobile and unreactive with, or inaccessible to, mild reagents or extraction media.

This task had as its focus the development of selective extraction methods that will allow the direct measurement of sulfur content in each form. Therefore, selective extraction methods were needed for the major sulfur forms in coal, including elemental, pyritic, sulfatic, and organic sulfur. This study was a continuation of that of previous analytical method development for sulfur forms in coal which resulted in the successful isolation and quantitation of elemental and sulfatic sulfur. Super- and subcritical extractions with methanol or water with and without additives were investigated in an attempt to develop methods for pyritic and organic sulfur forms analysis in coal. Based on these studies, a sequential extraction scheme that is capable of selectively determining elemental, sulfatic, pyritic and two forms of organic sulfur is presented here. This scheme was also reported at several conferences $(E, F, G)$.

\subsection{OBJECTIVES}

The objective was to develop and validate analytically valid extraction and measurement techniques for all major sulfur forms in coal based on direct measurement. Secondary objectives were to investigate the transformation of sulfur forms and to determine potential processing implications of the extraction methods developed. For each of the extraction conditions, the major emphasis was on understanding the forms of sulfur removed (and/or transformed) with the primary goal of developing reliable analytical methodology.

Specific objectives were:

- To investigate and develop the use of SFE and pyrolysis-SFE for the selective extraction of true organic sulfur forms from coal. Also, to identify and quantitate the individual $S$ organics recovered from SFE procedures.

- To develop and evaluate SFE methods for pyrolysis, extraction, and analysis as needed to achieve mass balance between extracted and collected organic sulfur.

- To determine the relationship between various inorganic and organic sulfur forms using class-selective extractions and stable sulfur isotope ratio measurements.

- To evaluate and incorporate other promising sulfur speciation techniques. 
- To determine the effect of temperature and pressure with $\mathrm{CO}_{2}$ and additives on the selectivity of extraction for the different sulfur forms in coal.

- To determine the effect of temperature and pressure with water on the selectivity of extraction for the different sulfur forms in coal. These investigations will both determine the potential analytical applications and whether further investigations into coal sulfur removal as a processing method are warranted.

- To determine whether optimal conditions are generally applicable to different coals.

\subsection{EXPERIMENTAL}

\subsection{Sample Preparation}

Bituminous coals (IBC-101, IBC-102, IBC-106, and IBC-107) obtained from the Illinois Basin Coal Sample Program (IBCSP), and a washed and magnetically cleaned Indiana No. 3 coal sample, from Cyprus-AMAX Research and Development Center, were used for this investigation. All of the coal samples used in this work were ground under a stream of argon to $-75 \mu \mathrm{m}$ and stored under argon in plastic containers before use. Results from the proximate and sulfur form analyses of the coals are shown in Tables 1 and 2, respectively. Work on stable sulfur isotope mass spectrometry in identifying sulfur forms in IBC-101, IBC-102, IBC-106, IBC-107 and physically cleaned Indiana No. 3 was carried out in a collaborative study with the University of Leeds, Leeds, U.K. These coals were also extracted to determine quantitative variation in sulfate extraction between the ASTMrequired $4.8 \mathrm{M} \mathrm{HCl}$ extraction and the $1.0 \mathrm{M} \mathrm{HCl}$ extraction used by the stable isotope analysis group in University of Leeds, Leeds U.K. The effectiveness of nonhalogenated acids for the extraction of sulfate sulfur was also tested on these coals.

Elemental sulfur-free coal (1) was prepared in 5-g quantities using a Suprex Prepmaster pump (Suprex Corp., Pittsburgh, PA, USA) under mild SFE conditions $\left(\mathrm{CO}_{2} / 10 \%\right.$ methanol, 400 atm, $110^{\circ} \mathrm{C}, 100 \mathrm{~min}$ ) and a 10.4-mL Keystone SFE extraction cell (Keystone Scientific, Bellefonte, PA, USA). A 10-cm-long crimped stainless steel tube (1/16 in. OD $\times 0.020$ in. ID) was attached at the outlet of the extraction cell to regulate the fluid flow (typically $1.5 \mathrm{~mL} / \mathrm{min}$ as pressurized fluid measured at the pump), and the extracted effluent was collected by depressurizing into a sample vial containing $3 \mathrm{~mL}$ of toluene (Optima grade, Fisher Scientific, Pittsburgh, PA, USA). Extracted elemental sulfur was determined using gas chromatography with atomic emission detection (GC-AED) (1).

\section{TABLE 1}

Proximate and Total Sulfur Analysis of Coal Samples, wt $\%$

\begin{tabular}{lrrrrr}
\hline & IBC-101 & IBC-102 & IBC-106 & IBC-107 & Indiana No. 3 \\
\cline { 2 - 6 } Moisture & 13.56 & 14.01 & 10.49 & 11.16 & 4.84 \\
Volatiles, mf & 41.43 & 39.89 & 40.27 & 39.85 & 41.74 \\
Fixed C, mf & 48.35 & 53.95 & 51.21 & 48.78 & 46.82 \\
Ash, mf & 10.24 & 6.20 & 8.51 & 11.37 & 11.53 \\
Total S & 4.31 & 3.07 & 3.59 & 3.44 & 4.20 \\
\hline
\end{tabular}

${ }^{1}$ Moisture-free. 
TABLE 2

Sulfur Form Analysis of Coal Samples ${ }^{1}$, wt $\%$ mf

\begin{tabular}{cccccc}
\hline Coal Sample & Elementa $^{2}$ & Sulfatic & Pyritic & Organic $^{3}$ & Total \\
\hline IBC-101 & 0.11 & 0.67 & 0.53 & 3.13 & 4.44 \\
IBC-102 & 0.35 & 1.17 & 0.61 & 1.14 & 3.27 \\
IBC-106 & 0.20 & 0.73 & 0.72 & 2.03 & 3.68 \\
IBC-107 & 0.05 & 0.37 & 0.42 & 2.75 & 3.59 \\
Indiana 3 $^{4}$ & ND & 0.83 & 0.49 & 3.09 & 4.41 \\
\hline
\end{tabular}

${ }^{1}$ Analyses performed by Minnesota Valley Testing Laboratories, Inc., Bismarck, ND

2 Values from Reference 1.

${ }^{3}$ Organic sulfur adjusted to account for elemental sulfur.

4 Physically cleaned.

\subsection{Super- and Subcritical Fluid Extractions Under Pyrolysis Conditions}

Pyrolysis-SFE experiments using supercritical $\mathrm{CO}_{2}$ at $450^{\circ} \mathrm{C}$ and $400 \mathrm{~atm}$ were performed on 50-mg coal samples that were mixed with $50 \mathrm{mg}$ of clean sand (sea sand, Fisher Scientific). The presence of the sand prevented the bituminous coal samples from agglomerating on heating, preventing maximum fluid-coal contact. Modifying the polarity of the extraction fluid was accomplished by use of premixed $10 \%$ ( $v / v$ ) methanol in $\mathrm{CO}_{2}$ (Scott Specialty Gases) for 30-min extractions unless other additives were used. Additives, including approximately $200 \mu \mathrm{L}$ of $85 \%$ phosphoric acid, ethanol, or glacial acetic acid, were spiked on the sample, rather than premixed with the $\mathrm{CO}_{2}$, and then extracted using pure supercritical $\mathrm{CO}_{2}$. In later pyrolysis-SFE experiments, $\mathrm{H}_{2} \mathrm{O}$ was used as the extraction fluid in place of $\mathrm{CO}_{2}$. The extraction cell was pressurized to 400 atm and held under static conditions while the gas chromatography oven was heated rapidly at about $32^{\circ} \mathrm{C} / \mathrm{min}$ to $450^{\circ} \mathrm{C}$ (requiring about $13 \mathrm{~min}$ ). The dynamic constant flow extraction was then begun and continued for $30 \mathrm{~min}$ at $400 \mathrm{~atm}$ and $450^{\circ} \mathrm{C}$.

Following extraction, the gas chromatography oven was cooled to ambient temperature before the extraction cell was detached from the extraction line for safety and to prevent any possible loss of material. The entire content of the extraction cell was collected and analyzed for total sulfur in accordance with ASTM guidelines. The amount of sulfur species removed from either untreated or treated coal feeds (expressed in percentage of sulfur removed) was determined by comparing the total sulfur content in the SFE-extracted residues (in mg of sulfur) with that in the untreated raw coal (in $\mathrm{mg}$ of sulfur). Therefore, all of the forms analysis used in this study were based on direct determination of sulfur content.

\subsection{Evaluation of Mass Balance and Selectivity of ASTM D2492 and of SFE and Pyrolysis-SFE}

To evaluate the selectivity and sulfur mass balance achieved with the ASTM D2492 sulfur form analysis method, sulfate sulfur-free coal was prepared according to the $\mathrm{HCl}$ extraction procedure defined by ASTM D2492 (2). Two-gram coal samples were extracted with boiling $4.8 \mathrm{~N}$ $\mathrm{HCl}$, washed with water, filtered, and dried in an oven at $100^{\circ} \mathrm{C}$ for $2 \mathrm{hr}$. The sample was then 
stored under argon in plastic containers until used. Similarly, coal samples that were free of elemental and sulfate sulfur were obtained by performing $\mathrm{HCl}$ batch extractions on elemental sulfurfree coal samples.

Pyritic and sulfatic sulfur-free coal samples were obtained by performing $\mathrm{HNO}_{3}$ batch extractions on both raw and elemental sulfur-free coal samples in accordance with ASTM Method D2492 (2). Two-gram coal samples were extracted with boiling $2 \mathrm{~N} \mathrm{HNO}_{3}$, washed with water, filtered, and dried in an oven at $100^{\circ} \mathrm{C}$ for $2 \mathrm{hr}$. The samples were then stored under argon.in plastic containers until used.

To complete the evaluation, large quantities of elemental sulfur-free, elemental sulfur-sulfatic sulfur-free, and elemental sulfur-sulfatic sulfur-pyritic sulfur-free coals were required. One hundred grams of elemental sulfur-free coal was prepared in 5-g batches, and the extracted residues were combined. This elemental sulfur-free coal was then divided into thirds, one of which was left intact, one was used to prepare elemental sulfur-sulfatic sulfur free coal, and the last one-third was used to prepare elemental sulfur-sulfatic sulfur-pyritic sulfur free coal. Following is a brief description of the methods used for preparing these samples:

One hundred grams, each, of elemental sulfur-free IBC-101 and IBC-107 were prepared by extracting each coal under mild SFE conditions $\left(\mathrm{CO}_{2} / 10 \%\right.$ methanol, $400 \mathrm{~atm}, 110^{\circ} \mathrm{C}$, $100 \mathrm{~min}$ ) as previously reported (1). Each extracted solid was divided into three fractions as mentioned above. One fraction was later extracted at $50^{\circ} \mathrm{C}, 250^{\circ} \mathrm{C}$ and $450^{\circ} \mathrm{C}$ with supercritical modified $\mathrm{CO}_{2}$ and with super- and subcritical $\mathrm{H}_{2} \mathrm{O}$. The second fraction was to have sulfate removed. Formic acid was used to extract sulfate since it was shown earlier in this study to be more selective for sulfate than the ASTM D2492-recommended 4.8 M HC] (B). Sulfate and pyrite was removed from the third fraction by extraction with the Canfield reagent (chromous acid) which was determined in early experiments to be more selective for the removal of inorganic sulfur than the usual $\mathrm{HNO}_{3}$ called for by ASTM D2492 (C, D).

Elemental sulfur-sulfate sulfur-free coal was prepared by extracting elemental sulfur free coal according to the method developed in this laboratory (3). In accordance with this procedure, elemental sulfur-free coal was extracted with boiling $4.8 \mathrm{~N} \mathrm{HCOOH}$, washed with water, filtered and dried in an oven at $100^{\circ} \mathrm{C}$ for $2 \mathrm{hr}$. The sample was then stored under argon in plastic containers until used.

Elemental sulfur-sulfate sulfur-free-pyrite sulfur-free coal samples were obtained by performing Canfield batch extractions of inorganic sulfur from both IBC-101 and IBC-107 elemental sulfur-free coal samples (4). In this procedure, elemental sulfur-free coal was treated with chromous acid to reduce inorganic sulfur for removal as $\mathrm{H}_{2} \mathrm{~S}$. The $\mathrm{H}_{2} \mathrm{~S}$. was collected as $\mathrm{CuS}$ in a liquid trap by purging the reaction vessel with $\mathbf{N}_{2}$. The residue was collected on Whatman No. 1 filter paper, washed with formic acid to remove residual chromium, dried, and stored under argon in plastic containers until used.

To evaluate the selectivity of sub- and supercritical fluid extraction, a series of extractions were carried out on samples of elemental sulfur-free, elemental sulfur-sulfate sulfur-free and elemental sulfur-sulfate sulfur free-pyrite sulfur-free IBC-101 and IBC-107 prepared as described above. Extractions were carried out at $50^{\circ} \mathrm{C}, 250^{\circ} \mathrm{C}$ and $450^{\circ} \mathrm{C}$ with $\mathrm{CO}_{2} / 10 \%$ methanol. The second fluid, sub- and supercritical $\mathrm{H}_{2} \mathrm{O}$, was used to extract the coals at $50^{\circ} \mathrm{C}, 250^{\circ} \mathrm{C}, 350^{\circ} \mathrm{C}$ and 
$450^{\circ} \mathrm{C}$. The extraction cell was a $0.5-\mathrm{mL}$ empty high-performance liquid chromatography (HPLC) cell (locally referred as a high-temperature extraction cell) from Keystone. Fifty milligrams of each sample was extracted at a fluid flow rate of $1.5 \mathrm{~mL} / \mathrm{min}$. Duplicate extractions at each set of conditions were performed.

\subsection{RESULTS AND DISCUSSION}

This project involved the development of a series of procedures with which sulfur forms can be measured directly, quickly, accurately, and economically. The strategy involved removal of elemental, sulfatic, pyritic, easy organic and hard organic forms by sequential extractions and measurement of the sulfur. As described earlier, easy organic sulfur is defined as the organic sulfur that can be removed from coal by laboratory extraction or pyrolytic thermal (up to $450^{\circ} \mathrm{C}$ ) methods, while hard organic sulfur is organic sulfur that resists removal from coal by these methods. The methods for each form, including the procedure and experimental results, have been published in refereed journals (see Section 7.0). The reader is referred to publications relating the results of this project cited at the end of this report.

\subsection{Supercritical $\mathrm{CO}_{2}$ Extractions of Elemental S Under Mild Conditions}

This study was based on background work where investigations were designed to develop and evaluate extraction methods for their ability to provide reliable and accurate extraction of the various sulfur forms for direct analytical determinations. A selective extraction method for determining elemental sulfur content of coal was previously developed at EERC and has been reported (1). This method, based on dynamic, constant-flow $\mathrm{CO}_{2} / 10 \%$ methanol at $110^{\circ} \mathrm{C}$ and 400 atm in 30 min gives quantitative results, selectively removing elemental sulfur. Using $\mathrm{CO}_{2} / 10 \%$ methanol $\left(110^{\circ} \mathrm{C}, 400\right.$ atm) as an extraction fluid, a kinetic study showed that elemental sulfur in coals was extracted quantitatively and selectively under dynamic conditions within $30 \mathrm{~min}$. Prior to method development for extraction of additional forms, the elemental extraction method was used to remove elemental sulfur from $100 \mathrm{~g}$ of each of five coal samples. The wt\% elemental sulfur extracted from each is reported in Table 2.

\subsection{Nonaqueous Extractions of Sulfatic, Pyritic and Easy Organic S under Conditions of Increasing Severity}

Forms of sulfur other than elemental $\mathrm{S}$ were unmoved by sulfur extraction methods based on dynamic, constant-flow SFE under low temperatures $\left(110^{\circ} \mathrm{C}, 400 \mathrm{~atm}\right)$. Therefore, elemental sulfurfree IBC-101 and Indiana No. 3 were extracted in triplicate under static conditions with the additives shown in Table 3, followed by dynamic extraction with supercritical $\mathrm{CO}_{2}$ at $450^{\circ} \mathrm{C}$ and $400 \mathrm{~atm}$, to determine the effect of additives on removing other sulfur forms. $\mathrm{SF} \mathrm{CO}_{2}$ (no additives) extraction under pyrolysis conditions $\left(450^{\circ} \mathrm{C}, 400 \mathrm{~atm}\right)$ on IBC-101 removed approximately $50 \%$ of the total sulfur as shown in Table 3. Spiking the coal sample with acetic acid or ethanol, followed by extraction with $\mathrm{CO}_{2}$, was no more effective in removing sulfur at $450^{\circ} \mathrm{C}$ and 400 atm than extraction with $\mathrm{CO}_{2}$ without additives. However, extraction with $\mathrm{CO}_{2} / 10 \%$ methanol under the same conditions removed approximately $60 \%$ of the total sulfur, and $\mathrm{SF} \mathrm{CO}_{2}$ with $\mathrm{H}_{3} \mathrm{PO}_{4}$ spiked on the coal sample removed approximately $80 \%$ of the total sulfur at $450^{\circ} \mathrm{C}$ and $400 \mathrm{~atm}$. Table 3 also shows that extraction of physically cleaned Indiana No. 3 with $\mathrm{CO}_{2} / 10 \%$ methanol and $\mathrm{CO}_{2}$ with the $\mathrm{H}_{3} \mathrm{PO}_{4}$ additive gave results similar to those from extraction of IBC-101 under the same conditions. 


\section{TABLE 3}

Percentage of Sulfur Removal from Elemental Sulfur-Free IBC-101 and Indiana No. 3 with Various Supercritical Fluids

\begin{tabular}{lcc}
\hline & \multicolumn{2}{c}{ Percentage of Total Sulfur Removed } \\
\cline { 2 - 3 } $\begin{array}{l}\text { Supercritical } \\
\text { Fluids/Reagent }\end{array}$ & IBC-101 & $\begin{array}{c}\text { Indiana No. 3 } \\
\text { Physically Cleaned }\end{array}$ \\
\hline $\mathrm{CO}_{2}$ & $49 \pm 1$ & $--^{2}$ \\
$\mathrm{CO}_{2}$ /Methanol & $62 \pm 3$ & $60 \pm 7$ \\
$\mathrm{CO}_{2}$ /Acetic Acid & $43 \pm 2$ & - \\
$\mathrm{CO}_{2}$ /Ethanol & $48 \pm 1$ & - \\
$\mathrm{CO}_{2}$ /Phosphoric Acid & $82 \pm 3$ & $78 \pm 9$ \\
\hline
\end{tabular}

1 Standard deviations are based on triplicate 30 -min extractions.

2 Not determined.

Table 4 shows that under pyrolysis and dynamic SFE conditions using pure $\mathrm{CO}_{2}$, with the addition of phosphoric acid, ca. $80 \%$ of the total sulfur was removed from two bituminous coal samples (IBC-101 and physically cleaned Indiana No. 3) regardless of whether the sulfatic sulfur or both the sulfatic and pyritic sulfur were removed prior to pyrolysis-SFE. However, when pyrolysis and dynamic SFE was performed with $\mathrm{CO}_{2} / 10 \%$ methanol, organic sulfur species appeared to be extracted preferentially, since only ca. $60 \%$ of the total sulfur was removed from the raw coal by pyrolysis-SFE using $\mathrm{CO}_{2} / 10 \%$ methanol, while ca. $80 \%$ of the total sulfur was extracted if sulfatic and pyritic sulfur were removed prior to extraction. Although removal of sulfur by $\mathrm{CO}_{2} / 10 \%$ methanol appears to extract organic sulfur preferentially, there is little evidence that it is selective toward organic sulfur under the conditions tested.

The results shown in Table 4 using the raw, sulfate-free, and sulfate- and pyrite-free IBC-101 and physically cleaned Indiana No. 3 coals demonstrate that pyrolysis-SFE conditions both with and without $\mathrm{H}_{3} \mathrm{PO}_{4}$ remove a substantial portion of the true organic sulfur. Assuming that the ASTMrecommended $\mathrm{HCl}$ liquid-solid extraction quantitatively removes sulfate and that the $\mathrm{HNO}_{3}$ extraction quantitatively removes sulfate and pyrite (errors with these methods are discussed later), the percentage of organic sulfur removed by $\mathrm{CO}_{2} / 10 \%$ methanol only, or by the spiking of coal with phosphoric acid followed by pyrolysis-SFE can be estimated. For example, if $70 \%$ of the sulfur in IBC-101 is organic and if $\mathrm{CO}_{2} / 10 \%$ methanol, combined with the $\mathrm{ASTM} \mathrm{HNO}_{3}$ extraction, removed $78 \%$ of the total sulfur, then the minimum calculated fraction of true organic sulfur extracted by pyrolysis-SFE with $\mathrm{CO}_{2} / 10 \%$ methanol would be $73 \%$ ( $78 \%$ total sulfur removed minus $27 \%$ inorganic removed by $\mathrm{HNO}_{3}$ equals $51 \%$ of total sulfur extracted by SFE, which is equivalent to $73 \%$ of the organic sulfur removed by SFE). This is the so-called easy organic sulfur. Similarly, pyrolysis-SFE with $\mathrm{CO}_{2} / 10 \%$ methanol extracts the easy organic sulfur from the Indiana No. 3 coal.

The results shown in Table 4 also demonstrate that the addition of $\mathrm{H}_{3} \mathrm{PO}_{4}$ causes the nonselective SFE of sulfate, pyrite, and a substantial portion of the organic sulfur. Again, assuming 
TABLE 4

Pyrolysis-SFE Sulfur Removal from IBC-101 and Indiana No. 3 Using Supercritical $\mathrm{CO}_{2} / 10 \%$ Methanol and $\mathrm{CO}_{2}$ /Phosphoric Acid

\begin{tabular}{|c|c|c|c|c|}
\hline \multirow[b]{3}{*}{ Coal Samples } & \multicolumn{4}{|c|}{ Sulfur Removal on Total Sulfur Basis ${ }^{1}$} \\
\hline & \multicolumn{2}{|c|}{$\mathrm{CO}_{2} / 10 \% \mathrm{MeOH}$} & \multicolumn{2}{|c|}{$\mathrm{CO}_{2} /$ Phosphoric Acid } \\
\hline & IBC-101 & $\begin{array}{c}\text { Physically } \\
\text { Cleaned } \\
\text { Indiana No. } 3\end{array}$ & IBC-101 & $\begin{array}{c}\text { Physically } \\
\text { Cleaned } \\
\text { Indiana No. } 3 \\
\end{array}$ \\
\hline Raw & $62 \pm 3$ & $60 \pm 7$ & $82 \pm 3$ & $78 \pm 9$ \\
\hline Sulfate-Free & $70 \pm 1$ & $72 \pm 1$ & $83 \pm 13$ & $85 \pm 23$ \\
\hline $\mathrm{S}_{8}$ - and $\mathrm{SO}_{4}$-Free & $68 \pm 1$ & $68 \pm 2$ & $81 \pm 12$ & $84 \pm 7$ \\
\hline $\mathrm{SO}_{4}-$ and $\mathrm{FeS}_{2}-\mathrm{Free}$ & $78 \pm 1$ & $76 \pm 3$ & $78 \pm 13$ & $81 \pm 12$ \\
\hline $\mathrm{S}_{8^{-}}, \mathrm{SO}_{4^{-}}$, and $\mathrm{FeS}_{2}$-free & $81 \pm 2$ & $72 \pm 4$ & $80 \pm 11$ & $74 \pm 10$ \\
\hline
\end{tabular}

${ }^{1}$ Standard deviations are based on triplicate 30 -min extraction.

that the $\mathrm{HNO}_{3}$ quantitatively extracts the sulfate and pyrite, the minimum fraction of organic sulfur extracted by pyrolysis/SFE with the addition of phosphoric acid would be $69 \%$ and $73 \%$ for IBC-101 and Indiana No. 3, respectively, which is in good agreement with the organic sulfur removed by pyrolysis SFE with $\mathrm{CO}_{2} / 10 \%$ methanol discussed above.

Extractions performed at elevated temperatures and under pressure may have an effect on coal matrices. Coal structure may be altered during SFE or hot-acid extractions, potentially affecting the sulfate sulfur determination. To determine the extent of these effects, thermogravimetric analysis (TGA) were performed on the untreated (raw coal), SFE-treated (elemental sulfur-free), SFE- and HCl-treated (elemental and sulfate sulfur-free), and SFE- and formic acid-treated (elemental and sulfate sulfur-free) IBC-101 coal samples. The moisture, volatile matter, combustible residue (fixed carbon), and noncombustible residue (ash) values determined are given in Table 5. Apart from a small reduction in the residue caused by mineral dissolution in the acid-treated samples (both $\mathrm{HCl}$ and formic), no differences are apparent in the amounts of thermally labile components of the SFEtreated, SFE-HCl-treated and SFE-formic acid-treated samples, indicating minimum structural changes of the raw coal as it undergoes these extractions. However, when the coal is extracted with nitric acid to remove pyritic sulfur according to ASTM D2492, the coal matrix undergoes severe changes, as indicated by the data in Table 5 .

As discussed above, pyrolysis-SFE removes substantial organic sulfur. In one test, to ensure that sulfur organic species were being extracted and to reduce the loss of extremely volatile sulfur species so that identification of major components would be possible, on-line pyrolysis-SFE-GC-MS (mass spectrometry), with supercritical $\mathrm{CO}_{2}$ at $450^{\circ} \mathrm{C}$ and 400 atm was used in the extraction and analysis of sulfur from $1 \mathrm{mg}$ of IBC-101. Pyrolysis-SFE extractd were collected cryogenically $\left(-50^{\circ} \mathrm{C}\right)$ at the inlet of a DB-5 GC column. Following the extraction, the condensed extract was analyzed by the GC-MS. Figure 1 shows the total ion chromatogram of this extract. Prominent organic sulfur species have been identified on the graph in Figure 1. 
TABLE 5

Proximate Analysis of Untreated, SFE-, HCl- and Formic Acid-Treated IBC-101 Samples

\begin{tabular}{|c|c|c|c|c|}
\hline Coal Sample & $\begin{array}{l}\text { Moisture, } \\
\text { wt\% }\end{array}$ & $\begin{array}{l}\text { Volatile Matter, } \\
\qquad \text { t } \%\end{array}$ & $\begin{array}{c}\text { Fixed Carbon, } \\
\text { wt } \%\end{array}$ & $\begin{array}{l}\text { Residue (ash), } \\
\text { wt\% }\end{array}$ \\
\hline Untreated & 9.0 & 35.8 & 44.6 & 10.5 \\
\hline$S_{8}$-Free & 5.0 & 36.5 & 47.6 & 11.0 \\
\hline $\mathrm{S}_{8}-$ and Sulfate-Free ${ }^{1}(\mathrm{HCl}$-extracted $)$ & 4.3 & 36.7 & 51.2 & 7.9 \\
\hline $\begin{array}{l}S_{8}-\text { and Sulfate-Free (formic acid- } \\
\text { extracted) }\end{array}$ & 5.4 & 37.5 & 49.8 & 7.3 \\
\hline $\begin{array}{l}\mathrm{S}_{8}^{-}, \mathrm{SO}_{4}^{-}, \text {Pyrite-Free } \\
\text { (Nitric acid-extracted) }\end{array}$ & 6.1 & 75.5 & 15.7 & 2.8 \\
\hline
\end{tabular}

${ }^{1}$ Performed using Method 5 (4.8 $\mathrm{M} \mathrm{HCl}$, air, gentle boil).

${ }^{2}$ Performed using Method $6(4.8 \mathrm{M} \mathrm{HCl}$, air, gentle boil).

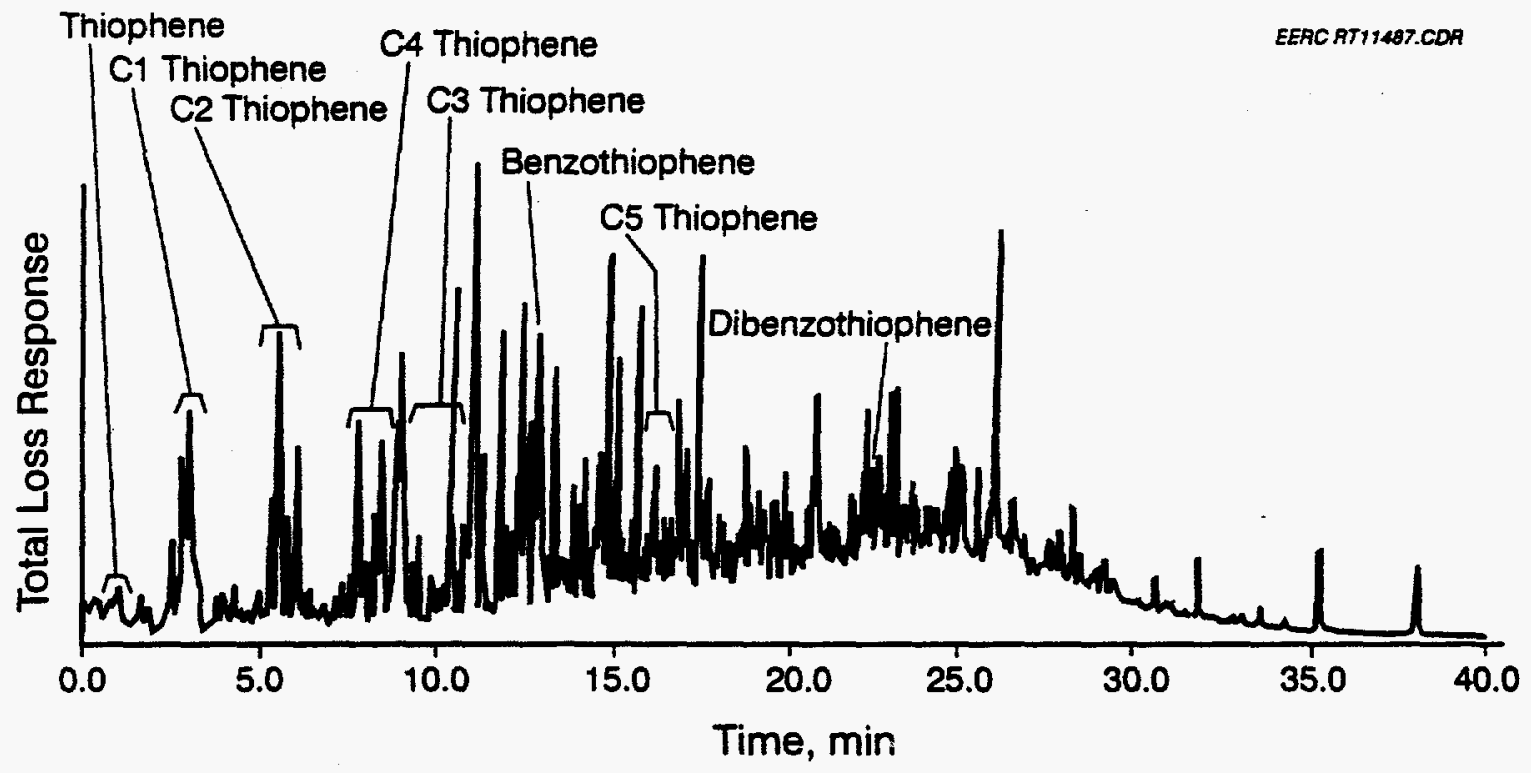

Figure 1. Total ion chromatogram of extract obtained by pyrolysis-SFE-GC-MS on-line extraction and detection of sulfur species from IBC-101. 


\subsection{Extraction of Sulfatic, Pyritic and Easy Organic S with Supercritical Water}

Supercritical water extraction, carried out at $450^{\circ} \mathrm{C}$ and 400 atm under static conditions for 15 min followed by dynamic conditions for $15 \mathrm{~min}$, gave encouraging results with IBC-101 bituminous coal, indicating that at least some organic sulfur could be extracted from coal (Table 6).

Approximately $2 / 3$ of the total sulfur was removed, indicating that all or part of each major sulfur fraction of coal (pyritic, sulfatic, and organic) was removed. Only ca. 1/3 of the carbon was removed at these extraction conditions.

Analyses by GC-AED showed numerous sulfur-containing compounds in both the IBC-101 and IBC-107 supercritical water extracts. GC-MS analysis of an SF $\mathrm{H}_{2} \mathrm{O}$ extract obtained at $450^{\circ} \mathrm{C}$ and $400 \mathrm{~atm}$ confirmed the presence of $\mathrm{CO}-\mathrm{C} 4$ alkylated thiophenes (e.g., tetramethyl- and diethylthiophene) and elemental sulfur. Other major species identified included naphthalene, alkyl naphthalenes, phenanthrene, alkyl phenanthrenes, alkyl phenanthrene, phenols, and $\mathrm{CO}-\mathrm{C} 3$ alkyl phenols. The AED chromatograms for sulfur and carbon in IBC-101 are shown in Figures 2 and 3, respectively, and for IBC-107 are shown in Figures 4 and 5, respectively.

\subsection{Comparison of Sub- and Supercritical $\mathrm{H}_{2} \mathrm{O}$ and with $\mathrm{CO}_{2} / 10 \%$ Methanol Extraction}

IBC-101 and IBC-107 bituminous coals from the IBCSP were extracted by classical liquid-solid methods and then by sub- and supercritical fluids to determine if selectivity in sulfur removal was probable. Acid extractions were used to remove sulfatic and pyritic sulfur forms from elemental sulfur-free fractions of IBC-101 and IBC-107 to determine the selectivity toward sulfatic, pyritic and organic sulfur forms of the sub- and supercritical fluid extractions. Elemental sulfur-free coal, obtained by extracting the raw coal with $\mathrm{CO}_{2} / 10 \%$ methanol at $110^{\circ} \mathrm{C}$ and $400 \mathrm{~atm}$, was prepared for subsequent extraction with acids. Because formic acid extraction for sulfate removal and chromous acid extraction for pyrite removal gave better sulfur mass balance than extraction with $\mathrm{HCl}$ and $\mathrm{HNO}_{3}$, they were used to prepare the samples for water extraction. Elemental and sulfate sulfur-free coal, obtained by extracting elemental-free coal with formic acid, and elemental and sulfate and pyrite sulfur-free coal, obtained by extracting elemental free coal by the Canfield (chromous acid) method, were extracted at several temperatures with $\mathrm{CO}_{2} / 10 \%$ methanol and with $\mathrm{H}_{2} \mathrm{O}$ at 400 atm.

In total, ninety-two extractions with sub- and supercritical $\mathrm{H}_{2} \mathrm{O}$ and $\mathrm{CO}_{2} / 10 \%$ methanol were performed, and the residues were analyzed for total sulfur by the combustion-iodine titrimetry. Duplicates were averaged to get the values reported in Tables 7 and 8 below.

\section{TABLE 6}

Extraction of Sulfur from Coal (IBC-101) with Supercritical Water

\begin{tabular}{cccc}
\hline Static Conditions & Dynamic Conditions & $\%$ s Reduction & $\%$ CReduction \\
$15 \mathrm{~min}$ at $\left(400 \mathrm{~atm}, 450^{\circ} \mathrm{C}\right)$ & $15 \mathrm{~min}$ at $\left(400 \mathrm{~atm}, 450^{\circ} \mathrm{C}\right)$ & $65.3 \pm 3.2$ & $33.9 \pm 0.9$ \\
\hline
\end{tabular}




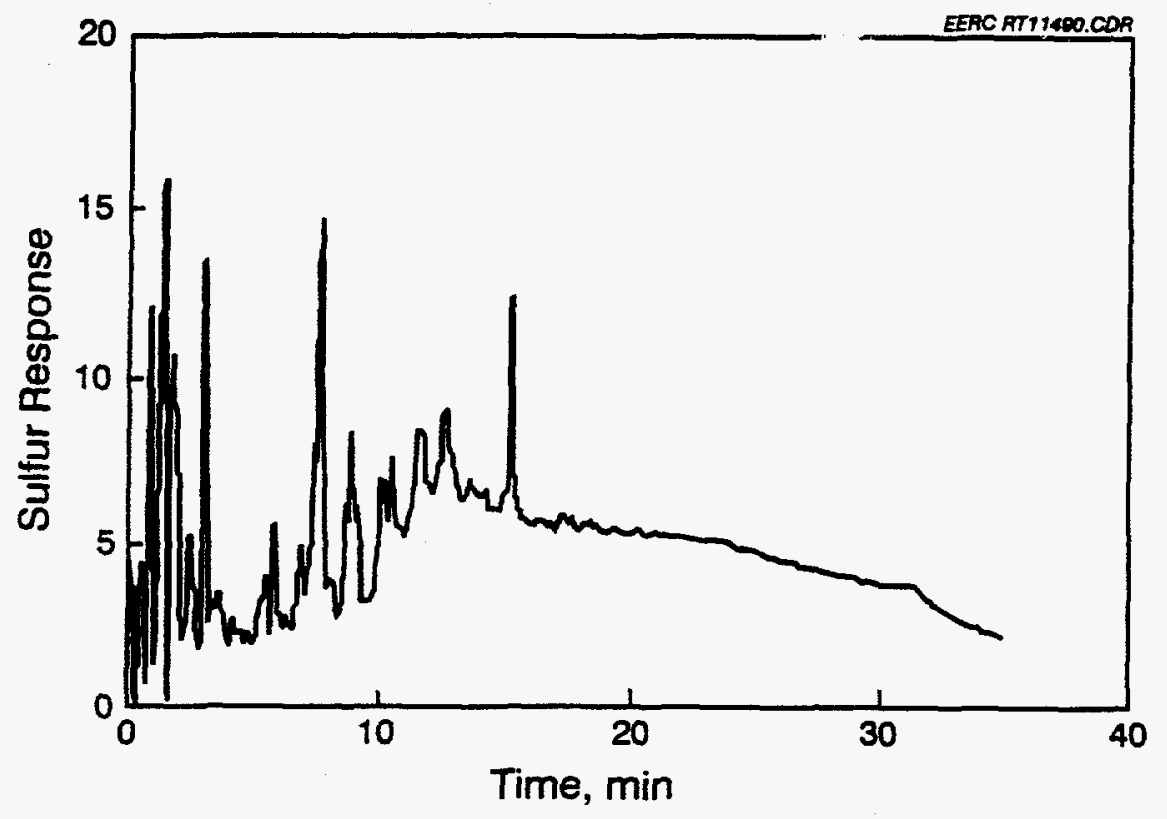

Figure 2. GC-AED chromatogram showing sulfur from various species contained in extract $\left(450^{\circ} \mathrm{C}, 400 \mathrm{~atm}\right)$ of IBC-101.

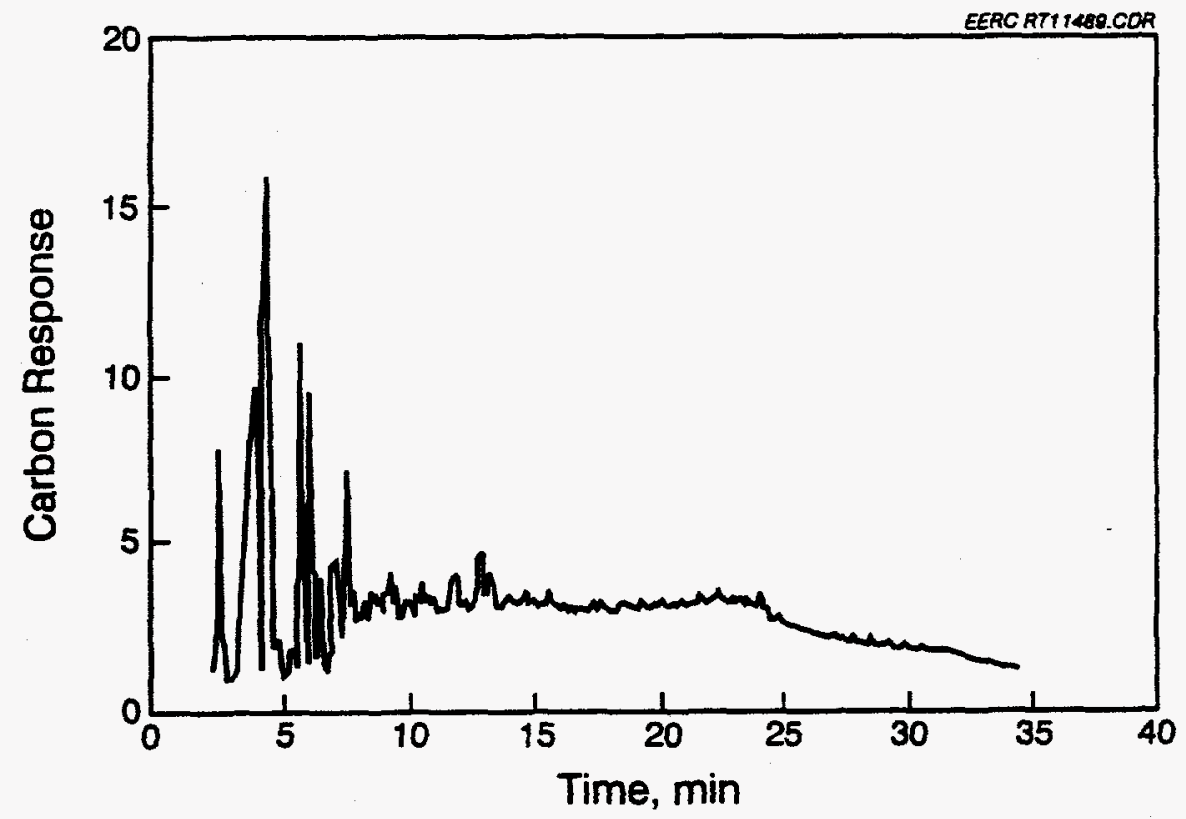

Figure 3. GC-AED chromatogram showing carbon from various species contained in extract $\left(450^{\circ} \mathrm{C}, 400 \mathrm{~atm}\right)$ of IBC- 101 . 


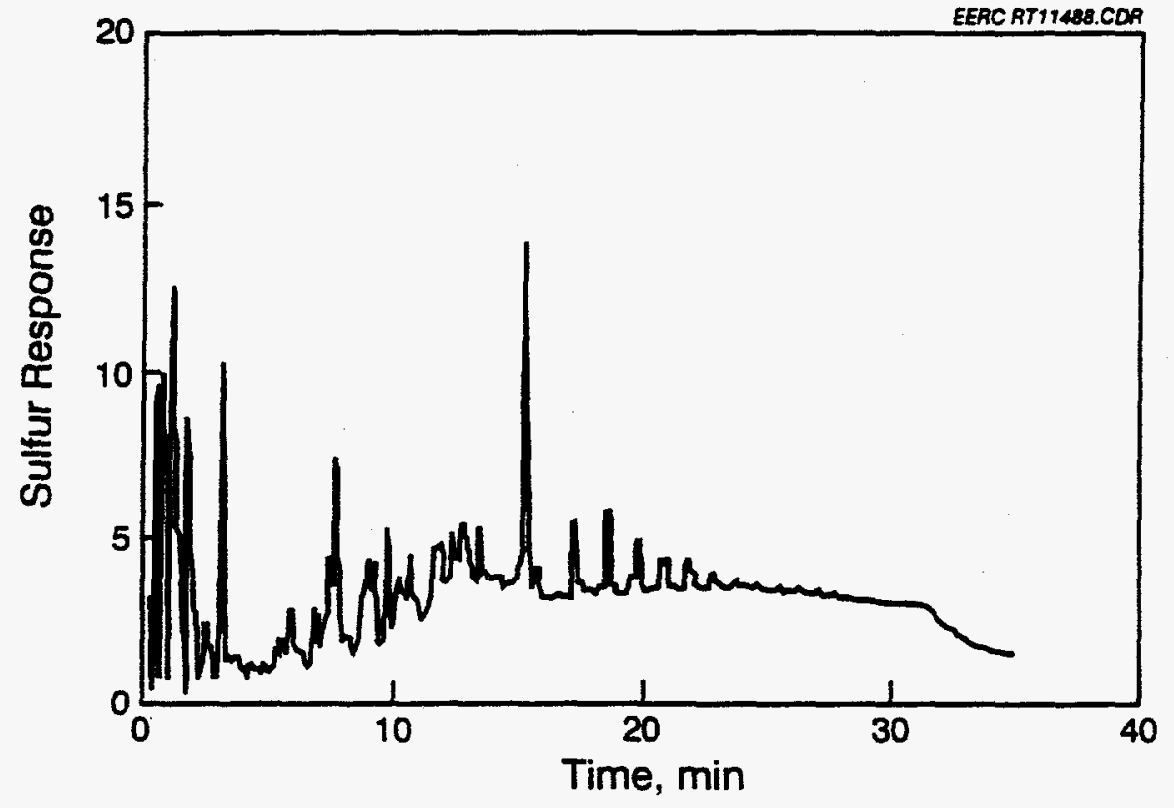

Figure 4. GC-AED chromatogram showing sulfur from various species contained in extract $\left(450^{\circ} \mathrm{C}, 400 \mathrm{~atm}\right)$ of IBC- 107.

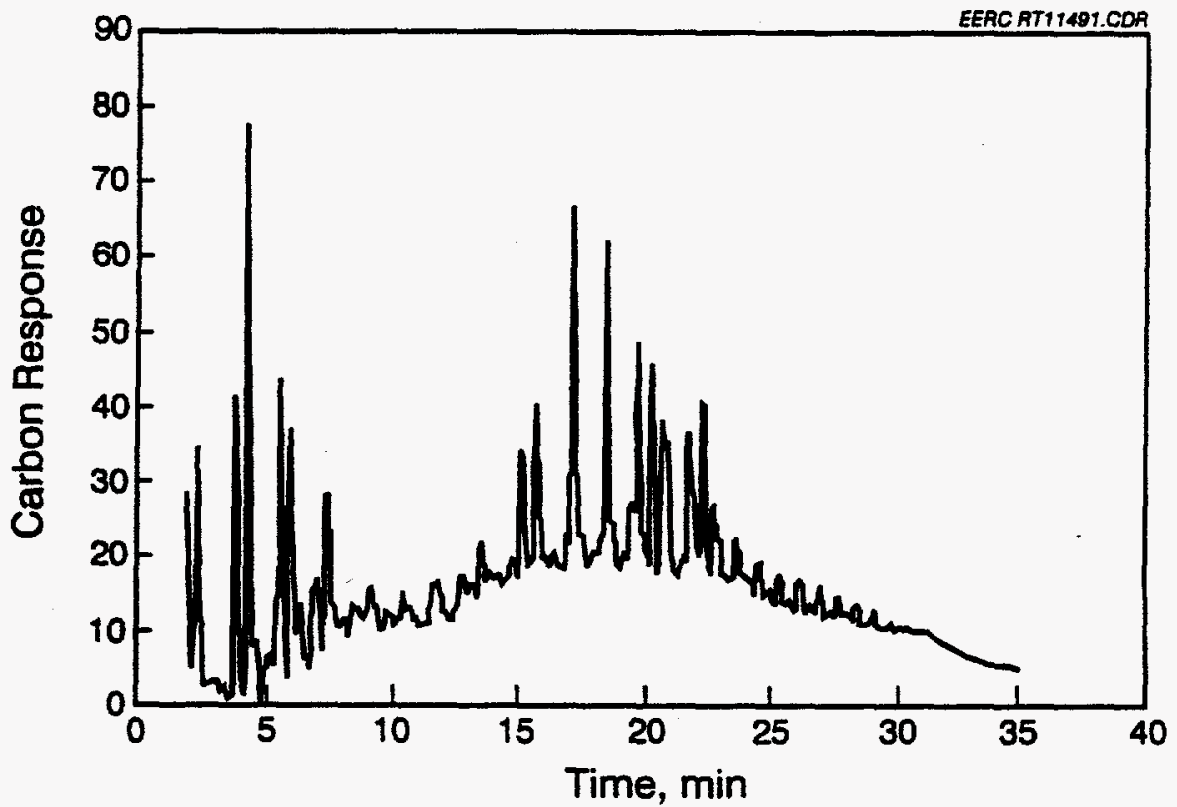

Figure 5. GC-AED chromatogram showing carbon from various species contained in extract $\left(450^{\circ} \mathrm{C}, 400 \mathrm{~atm}\right)$ of IBC- 107 . 


\section{TABLE 7}

Sulfur Removal from IBC-101 and IBC-107 Coals with $\mathrm{CO}_{2} / 10 \%$ Methanol at $400 \mathrm{~atm}, 30 \mathrm{~min}$

Wt\% ${ }^{1}$ Sulfur Removed From Treated Sample

Ext.

\begin{tabular}{|c|c|c|c|c|c|c|}
\hline emp., ${ }^{\circ} \mathrm{C}$ & \multicolumn{3}{|c|}{ IBC-101 } & \multicolumn{3}{|c|}{ IBC-107 } \\
\hline Raw & Coal & $\begin{array}{c}\mathrm{SO}_{4} \text {-Free } \\
\text { (Formic } \\
\text { Acid) }\end{array}$ & $\begin{array}{c}\mathrm{FeS}_{2}, \mathrm{SO}_{4}- \\
\text { Free } \\
\text { (Canfield) }\end{array}$ & $\begin{array}{c}\text { Raw Coal } \\
\text { (Formic } \\
\text { Acid) }\end{array}$ & $\begin{array}{c}\mathrm{SO}_{4} \text {-Free } \\
\text { (Canfield) }\end{array}$ & $\begin{array}{c}\mathrm{FeS}_{2}, \mathrm{SO}_{4}- \\
\text { Free }\end{array}$ \\
\hline 50 & 10 & 24 & 34 & 2 & 11 & 11 \\
\hline 250 & 10 & 30 & 36 & 2 & 12 & 13 \\
\hline 450 & 59 & 70 & 72 & 58 & 62 & 62 \\
\hline
\end{tabular}

${ }^{1}$ Average of duplicate extractions at $400 \mathrm{~atm}, 30 \mathrm{~min}$.

TABLE 8

Sulfur Removal from Coals IBC-101 and IBC-107 with Water at $400 \mathrm{~atm}, 30 \mathrm{~min}$

\begin{tabular}{|c|c|c|c|c|c|c|}
\hline \multirow{3}{*}{$\begin{array}{c}\begin{array}{c}\text { Ext. } \\
\text { Temp., }{ }^{\circ} \mathrm{C}\end{array} \\
\text { Raw }\end{array}$} & \multicolumn{5}{|c|}{ Wt $\%^{1}$ Sulfur Removed From Treated Sample } & \\
\hline & \multicolumn{3}{|c|}{ IBC-101 } & \multicolumn{3}{|c|}{ IBC-107 } \\
\hline & Coal & $\begin{array}{c}\mathrm{SO}_{4} \text {-Free } \\
\text { (Formic } \\
\text { Acid) }\end{array}$ & $\begin{array}{c}\mathrm{FeS}_{2}, \mathrm{SO}_{4} \\
\text { Free } \\
\text { (Canfield) }\end{array}$ & Raw Coal & $\mathrm{SO}_{4}$-Free & $\begin{array}{c}\mathrm{FeS}_{2}, \mathrm{SO}_{4}- \\
\text { Free }\end{array}$ \\
\hline 50 & 21 & 25 & 31 & 6 & 14 & 17 \\
\hline 250 & 29 & 06 & 32 & 12 & 10 & 18 \\
\hline 350 & 43 & 47 & 58 & 44 & 39 & 52 \\
\hline 450 & 56 & 78 & 78 & 73 & 70 & 76 \\
\hline
\end{tabular}

${ }^{1}$ Average of duplicate extractions at $400 \mathrm{~atm}, 30 \mathrm{~min}$.

The data in Table 7 shows that up to $72 \%$ of the sulfur can be removed from bituminous coal extracted at $450^{\circ} \mathrm{C}$ and $400 \mathrm{~atm}$ for $30 \mathrm{~min}$ with $\mathrm{CO}_{2} / 10 \%$ methanol, while Table 8 shows that up to $78 \%$ can be removed at the same conditions with $\mathrm{H}_{2} \mathrm{O}$. Of the $78 \%$, more than one half is organic sulfur as defined by the ASTM D2492 sulfur forms method. The unextracted sulfur, the so-called hard organic sulfur (22\% of the total), resists removal except under very severe conditions, e.g., much higher temperatures or combustion. 
Table 9 shows the initial data obtained by extracting IBC-101 and two additional bituminous coals (IBC-106 and physically cleaned Indiana No. 3) with supercritical water under dynamic conditions to emulate the best sulfur removal conditions from Table 8. The removal of all but the hard organic sulfur with $\mathrm{SF} \mathrm{H}_{2} \mathrm{O}$ indicates that this extraction technique is not coal-specific and, therefore, that sulfatic, pyritic and easy organic sulfur may be successfully extracted from coal with supercritical water. In addition, Table 9 shows that sulfur removal is affected more by extraction temperature than by sulfur form and that the effect of pressure may be coal dependent. Any apparent pressure dependence may be due to sulfur forms but may also be due to the reactivity of the coal matrix or mineral content.

\section{TABLE 9}

Removal of Sulfur under Sub- and Supercritical Water Extraction Conditions ${ }^{1}$

\begin{tabular}{|c|c|c|c|c|}
\hline Sample & $\begin{array}{c}\text { Extr. Temp., } \\
{ }^{\circ} \mathrm{C}\end{array}$ & $\begin{array}{c}\text { Extr. Press., } \\
\text { atm }\end{array}$ & Purge Gas & $\begin{array}{c}\text { S Removal as \% } \\
\text { of Total S }\end{array}$ \\
\hline IBC-101 & 50 & 400 & $\mathbf{N}_{2}$ & 4.8 \\
\hline IBC-106 & 50 & 400 & $\mathbf{N}_{2}$ & 2.2 \\
\hline Indiana No. 3 & 50 & 400 & $\mathbf{N}_{2}$ & 3.2 \\
\hline IBC-101 & 250 & 400 & $\mathbf{N}_{2}$ & 16.8 \\
\hline IBC-106 & 250 & 400 & $\mathbf{N}_{2}$ & 18.8 \\
\hline Indiana No. 3 & 250 & 400 & $\mathbf{N}_{2}$ & 11.8 \\
\hline IBC-101 & 350 & 400 & $\mathbf{N}_{2}$ & 51.3 \\
\hline IBC-106 & 350 & 400 & $\mathbf{N}_{2}$ & 36.0 \\
\hline Indiana No. 3 & 350 & 400 & $\mathbf{N}_{2}$ & 38.2 \\
\hline IBC-101 & 450 & 400 & $\mathbf{N}_{2}$ & 73.0 \\
\hline IBC-106 & 450 & 400 & $\mathrm{~N}_{2}$ & 71.4 \\
\hline Indiana No. 3 & 450 & 400 & $\mathbf{N}_{2}$ & 70.4 \\
\hline IBC-101 & 450 & 100 & $\mathbf{N}_{2}$ & 66.8 \\
\hline IBC-106 & 450 & 100 & $\mathbf{N}_{2}$ & 67.2 \\
\hline Indiana No. 3 & 450 & 100 & $\mathbf{N}_{2}$ & 82.6 \\
\hline IBC-101 & 450 & 400 & Air & 64.7 \\
\hline IBC-106 & 450 & 400 & Air & 74.1 \\
\hline Indiana No. 3 & 450 & 400 & Air & 70.3 \\
\hline
\end{tabular}

${ }^{1} 30$-min dynamic supercritical water extraction purged with $\mathrm{N}_{2}$ or air. 


\subsection{Selective Extraction of Sulfatic Sulfur and Evaluation of Mass Balance}

Selective extraction of elemental sulfur and other forms of sulfur (leaving hard organic sulfur in the residue) resulted in methods for the direct determination of two forms of sulfur in coal. Methods for direct determination of sulfatic, pyritic, and easy organic sulfur were also developed in this study.

Elemental sulfur was extracted from four coals (IBC-101, IBC-102, IBC-106, and IBC-107) with supercritical $\mathrm{CO}_{2} / 10 \%$ methanol at $110^{\circ} \mathrm{C}$ and $400 \mathrm{~atm}$. The residues were then analyzed in duplicate for $\mathrm{SO}_{4}^{-2}$ by the ASTM sulfate method described in D2492. This procedure, in which $\mathrm{Ba}^{+2}$ is used to precipitate the $\mathrm{SO}_{4}^{-2}$ after it has been extracted from the coal with hot $\mathrm{HCl}$, is a relatively simple, straightforward gravimetric method to directly determine that form of sulfur. To test this method and its reproducibility and to compare it with the method used by Dr. Simon Bottrell of the University of Leeds, UK, (Methods 1 and 2 in Table 10) for obtaining sulfur forms for stable sulfur isotope analyses in his laboratory, the coals were extracted in duplicate under air and under $\mathrm{N}_{2}$ at two temperatures. Table 10 shows the results obtained with these extractions. Reproducibility of results for all duplicates was excellent. No real difference in $\mathrm{SO}_{4}{ }^{-2}$ levels was observed between the results of an extraction done at a given acid strength and at a given temperature under air compared with that

\section{TABLE 10}

Stable Sulfur Isotope Data of Sulfate Sulfur Obtained under Different Extraction Conditions

\begin{tabular}{|c|c|c|c|c|}
\hline Sample & Treatment/Extraction Method & $8^{34} S_{\operatorname{cor}^{1}}$ & $\begin{array}{l}\text { Sulfatic Sulfur in } \\
\text { Coal, wt } \%\end{array}$ & $\begin{array}{c}\text { Sulfur } \\
\text { Rocovery, } \%\end{array}$ \\
\hline IBC-101 & Method 1 (4.8 M HCl, air, gentle boil) & +1.0 & 0.67 & 96.37 \\
\hline IBC-102 & Method 1 (4.8 M HCl, air, gentle boil) & +5.1 & 1.03 & 91.79 \\
\hline IBC-106 & Method 1 (4.8 M HCl, air, gentle boil) & +5.8 & 0.80 & 92.21 \\
\hline IBC-107 & Method 1 (4.8 M HCl, air, gentle boil) & +16.0 & 0.34 & 87.17 \\
\hline IBC-101 & Method $2\left(1 \mathrm{M} \mathrm{HCl}, \mathrm{N}_{2}\right)$ & +1.6 & 0.59 & 91.01 \\
\hline IBC-101 & Method $3\left(1 \mathrm{M} \mathrm{HCl}, \mathrm{N}_{2}\right.$, heated to $\left.95^{\circ} \mathrm{C}\right)$ & +1.3 & 0.65 & 92.8 \\
\hline IBC-101 & Method $4\left(4.8 \mathrm{M} \mathrm{HCl}, \mathrm{N}_{2}\right.$, beated to $\left.95^{\circ} \mathrm{C}\right)$ & +1.2 & 0.64 & 94.22 \\
\hline IBC-101 & Method $5\left(4.8 \mathrm{M} \mathrm{HCl}\right.$, air, beated to $\left.95^{\circ} \mathrm{C}\right)$ & +0.3 & 0.70 & 93.63 \\
\hline IBC-107 & Method $2\left(1 \mathrm{M} \mathrm{HCl}, \mathrm{N}_{2}\right)$ & +16.8 & 0.31 & 82.99 \\
\hline IBC-107 & Method $3\left(1 \mathrm{M} \mathrm{HCl}, \mathrm{N}_{2}\right.$, heated to $\left.95^{\circ} \mathrm{C}\right)$ & +19.3 & 0.32 & 83.81 \\
\hline IBC-107 & Method $4\left(4.8 \mathrm{M} \mathrm{HCl}, \mathrm{N}_{2}\right.$, heated to $\left.95^{\circ} \mathrm{C}\right)$ & +17.3 & 0.35 & 83.42 \\
\hline IBC-107 & Method $5\left(4.8 \mathrm{M} \mathrm{HCl}\right.$, air, heated to $\left.95^{\circ} \mathrm{C}\right)$ & +17.2 & 0.36 & 83.52 \\
\hline IBC-101 & Method 6 ( $4.8 \mathrm{M}$ formic acid, air, gentle boil) & +1.5 & 0.61 & 94.7 \\
\hline IBC-102 & Method 6 (4.8 M formic acid, air, gentle boil) & +7.3 & 0.93 & 95.28 \\
\hline IBC-106 & Method 6 (4.8 M formic acid, air, gentle boil) & +7.7 & 0.64 & 100.30 \\
\hline IBC-107 & Method 6 (4.8 M formic acid, air, gentle boil) & +18.2 & 0.34 & 95.49 \\
\hline
\end{tabular}

' CDT, Canyon Diablo Troilite. 
done under $\mathrm{N}_{2}$. Slightly more sulfate was extracted from the IBC-101 and the IBC-107 with the 4.8 $\mathrm{M}$ (ASTM) $\mathrm{HCl}$ than with the $1 \mathrm{M} \mathrm{HCl}$. Total sulfur analyses of the extracted residues gave resuits similar to those just described for the sulfate analyses of the corresponding extract. However, in calculating sulfur mass balance, there appeared to be only slight loss of sulfur in IBC-101, but a much greater loss of sulfur in the IBC-107, indicating that the $\mathrm{HCl}$ extraction is removing sulfur species in addition to $\mathrm{SO}_{4}^{-2}$ and suggesting that the $\mathrm{HCl}$ extraction method is coal-specific. These results reveal a second source of error in the ASTM sulfur forms analysis (the first being the lack of determination of elemental sulfur, thus lumping it in with the "organic" sulfur value that is calculated by difference).

To address the problem of poor mass balance in some coals (represented here by IBC-107), other acids were used to extract the sulfate from the four elemental sulfur-free coals. Stable sulfur isotope mass spectrometry (SSIMS) was used to support conclusions on benefits of an alternative acid used in place of ASTM HCl. (For additional information on the application of SSIMS in this study see section below.) The method was identical to that used in the $\mathrm{HCl}$ extractions, except that the phosphoric and formic acids were substituted for the $\mathrm{HCl}$. As expected, the phosphate coprecipitated with the sulfate, giving a barium residue eight times that expected for the pure barium sulfate. The formic acid extract, however, yielded sulfate results identical to those of the $\mathrm{HCl}$ extracts, but, even more importantly, gave sulfur mass balance results much better than those of $\mathrm{HCl}$-extracted samples. These results indicate that nonsulfate sulfur species are extracted by $\mathrm{HCl}$ but are not precipitated by $\mathrm{Ba}^{+2}$ as $\mathrm{BaSO}_{4}$ and, therefore, are counted as organic sulfur in the difference calculation. Formic acid, however, leaves these species intact for later measurement. The mass balance results in Table 10 can be compared to see the improvement because of the formic acid extraction. A concise article on this part of the study was published in Fuel (B).

While sulfate sulfur yields from coal samples IBC-101, $-102,-106$ and -107 obtained by extraction with formic acid appeared to be consistent with the yields obtained using the ASTM $\mathrm{HCl}$ method and, in addition, yielded superior sulfur mass balance values, determination of the sulfate sulfur by an independent method (such as SSIMS) was needed to confirm the sulfate results. Stable sulfur isotope mass spectroscopy, based on the natural isotopic ratios $\left(\delta^{34} S / \delta^{32} S\right)$ of sulfur, successfully confirmed that formic acid extraction of sulfate was superior to the current ASTM $\mathrm{HCl}$ extraction in terms of selectivity and sulfur mass balance. A report of SSIMS results from this study has been published in Fuel (D).

Sulfur mass balance for this suite of samples is greatly improved in samples where sulfate is extracted with formic acid before extracting pyrite sulfur and organic sulfur, except in IBC-101 as shown by Table 10. Sulfur closure for IBC-101 is nearly the same whether formic acid is used in the extraction sequence or not.

\section{6 ${ }^{34} \mathrm{~S} /{ }^{32} \mathrm{~S}$ Ratios of Sulfur Forms Extracted from Bituminous Coals}

SSIMS has been successfully applied in tracking sulfur and differentiating sulfur forms in coals. This method is particularly valuable in analyzing ${ }^{34}$ S-enriched samples such as IBC-107, and it is for this reason that much of our stable sulfur isotope work, and that of Hackley et al. (4), has focused on that coal before being extended to the other coals. A comparison of sulfate sulfur obtained with formic acid extraction and the standard ASTM $\mathrm{HCl}$ extraction method was obtained from the corresponding $\delta^{34} S / \delta^{32} S$ values. Any significant amount of pyritic and organic sulfur coextracted with sulfate sulfur and subsequently counted as sulfate sulfur could be observed by the 
stable sulfur isotope results. To this end, sulfate sulfur samples in the form of barium sulfate, obtained under extraction conditions different from those under which coal samples IBC-101, -102, -106 , and -107 were analyzed by stable sulfur mass spectroscopy. The $\delta^{34} S$ values obtained were given in Table 10. The corresponding weight percent sulfate sulfur in coal and percent sulfur recovery values were also given in Table 10 for comparison. Essentially the same $\delta^{34} S$ values were obtained for sulfate sulfur extracted from IBC-101, $-102,-106$ and -107 by using Method $1(+1.0$, $+5.1,+5.8$, and $+16.0 \%$ and Method $6(+1.5,+7.7,+7.7$, and $+18.2 \%$, which indicated that formic acid extracted the same sulfate fraction as the standard ASTM HCl method.

Similar $\delta^{34} S$ values on sulfate sulfur found in Table 10 were obtained under a broad range of $\mathrm{HCl}$ extraction conditions (Methods 2, 3, 4, and 5) from IBC-101 and IBC-107, supporting the previous findings that under all of the conditions tested, $\mathrm{HCl}$ extracted the same sulfate sulfur fraction. The $\delta^{34} \mathrm{~S}$ values of sulfatic, pyritic, and organic sulfur are +16.0 (Table 10), +26.4 (Table 11), and +1.6 (Table 11) respectively, for coal sample IBC-107. If a significant portion of the organic or pyritic sulfur were coextracted with either $\mathrm{HCl}$ or formic acid, the sulfate sulfur $\delta^{34} \mathrm{~S}$ values would have a less positive isotope ratio in the presence of organic sulfur (e.g., organic $\delta^{34} S$ value $+1.6 \%$ [4]) or a more positive isotope ratio in the case of pyritic sulfur contamination (e.g., pyritic $\delta^{34} \mathrm{~S}$ value $+26.4 \%$.

The small difference between our $\delta^{34} \mathrm{~S}$ sulfate numbers $(+16.0$ and $+18.2 \%$ obtained with ASTM $\mathrm{HCl}$ and formic acid extraction from IBC-107 and the $\delta^{34} \mathrm{~S}$ sulfate number reported by Hackley $(+13.2 \%$ ) probably resulted from the use of a more highly oxidized coal sample in the

TABLE 11

Sulfur Isotopic Composition of Fractions Obtained from IBC-107

\begin{tabular}{|c|c|c|c|}
\hline Sample & Preparation & $\delta^{34} \mathrm{~S}^{\circ} \mathrm{cos}^{1}$ & Error, \% \\
\hline 1 & Parr bomb oxidation of total coal & +6.5 & \pm 0.2 \\
\hline 2 & $\begin{array}{l}\text { Parr bomb oxidation of elemental S in SF extract } \\
\text { collected in toluene }\end{array}$ & +13.4 & \pm 0.2 \\
\hline $3 x$ & $\begin{array}{l}\text { Pyrite sulfur extracted from PL-3 by acidic chromous } \\
\text { chloride (Canfield method) }\end{array}$ & +26.4 & \pm 0.4 \\
\hline $3 r$ & $\begin{array}{l}\text { Organic } S \text { (residue from Canfield extraction) by Parr } \\
\text { bomb oxidation }\end{array}$ & +1.6 & \pm 0.2 \\
\hline 4 & Inorganic $S$ in Riley ${ }^{2}$ extract of PL-3 & +12.1 & \pm 0.2 \\
\hline 5 & $\begin{array}{l}\text { Organic } S \text { (residue from Riley extraction) by Parr } \\
\text { bomb oxidation }\end{array}$ & +1.5 & \pm 0.2 \\
\hline
\end{tabular}


present investigation. The sulfate sulfur in coal obtained in the present study was 0.34 wt\% compared with 0.26 wt\% reported by Hackley et al. (4). In addition, the sulfate sulfur yields from the Illinois coals obtained by using either $\mathrm{HCl}$ or formic acid are nearly identical (based on barium sulfate gravimetric method and stable sulfur isotope analysis), and a better sulfur mass balance was obtained with formic acid extraction. Therefore, the lack of sulfur mass balance (e.g., IBC-107) cannot be attributed to the loss of sulfate, but to an as-yet unidentified coal-dependent $\mathrm{HCl}$ acid reaction that results in a sulfur species which has not been collected.

Stable sulfur isotope analysis of the extracts of IBC-107 obtained by SFE (elemental S), $\mathrm{HNO}_{3}$ extraction (pyritic sulfur, or, in the case of raw coal, pyritic and sulfatic coal), and Canfield extraction (pyritic sulfur) (5) were carried out, and the results are shown in Table 11 (Sulfatic sulfur isotope values are given in Table 10.) The isotope ratio of the pyritic sulfur is said to be heavy since it has a relatively large amount of ${ }^{34} \mathrm{~S}(+26.4 \%$. Conversely, the organic sulfur ratio is said to be "light" because of its relatively small amount of ${ }^{34} \mathrm{~S}(+1.5 \%)$. Elemental sulfur has an isotope ratio of $+13.4 \%$ that is related to a combination of pyritic and organic sulfur, indicating that an interconversion pathway to or from elemental sulfur would include both forms. Similarly, the nitric acid extract of the coal has an isotope ratio of $+12.1 \%$ indicating that the nitric acid has extracted not only the intended pyritic sulfur but also some of the organic form. The residue from this extraction is uniquely organic, as indicated by the $+1.6 \%$ value. The sulfur isotope ratio for the sulfatic sulfur (about $+18 \%$ ) is most similar to that of pyritic sulfur, indicating that interconversion between those two forms is likely.

The results of stable sulfur isotope analysis of the formic acid, chromous acid, and nitric acid extracts of the elemental sulfur-free IBC-107 bituminous coal are shown in Table 11 and for all five of the coals in Table 12. The isotope ratio (expressed as $\delta^{34} \mathrm{~S}$ ) of the pyritic sulfur in the chromous acid (Canfield) extract is said to be "heavy" in IBC-101, IBC-106 and IBC-107, since they have a relatively large amount of ${ }^{34} \mathrm{~S}(+4.5,+10.3$, and $+27.9 \%$, respectively) when compared with the sulfatic sulfur $(+0.9,+0.5$, and $+11.1 \%$, respectively) and that of the organic sulfur $(-3.3$, +7.0 , and $+6.2 \%$, respectively). However, IBC-102 and Indiana No. 3 coals do not have isotopically "heavier" pyritic sulfur than sulfatic and organic sulfur. Little isotope difference is evident in IBC-102, but Indiana No. 3 has an isotopically heavier organic sulfur extract and a lighter sulfatic extract than the pyritic sulfur extract. Since the difference in ratios indicates probable difference in the sulfur reservoir, it appears that ${ }^{32} \mathrm{~S}$ is favored for incorporation into the organic matrix resulting in increased concentration of ${ }^{34} \mathrm{~S}$ in the inorganic fraction.

\subsection{Proposed Method for Selective Extraction and Determination of Sulfur Forms in Coal}

The results of these investigations allow us to propose a new approach to the selective determination of sulfur forms in coal. To the best of our knowledge, the experiments described in this report have been the first attempt to selectively extract and determine each major form of coal sulfur and to evaluate the procedures developed based on total mass balance (i.e., the total recovery of sulfur based on each selective extraction method as well as based on sulfur isotope analysis). The proposed approach is shown schematically in Figure 6, along with the technique used to measure each extracted sulfur form. 


\section{TABLE 12}

Stable Sulfur Isotope Ratios for Five Bituminous Coals

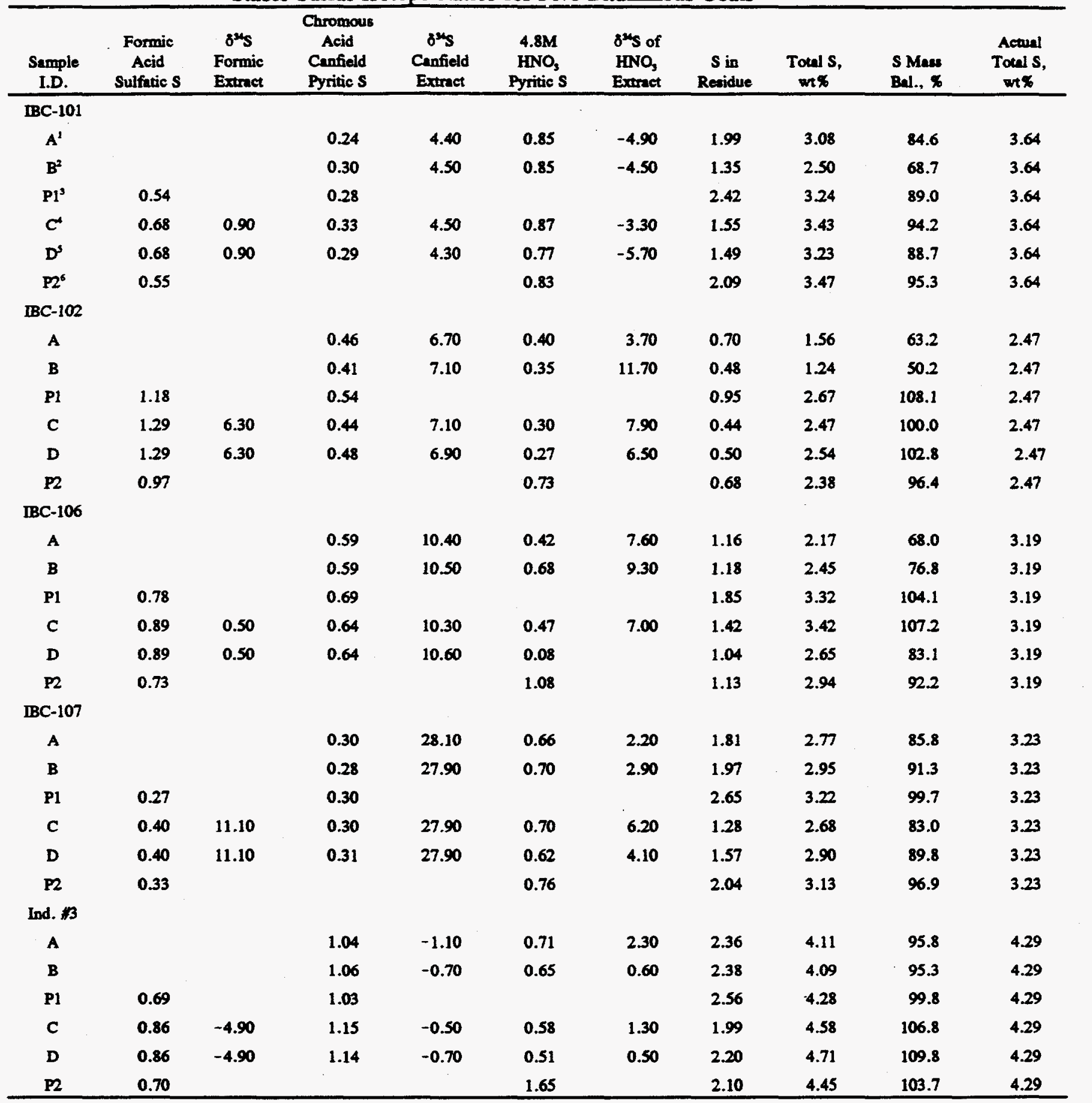

'Sample was not extracted with formic acid to remove wulfate.

${ }^{2}$ Repeat of A.

${ }^{3}$ Sample was not extracted with nitric acid.

4 Sample was extracted with formic acid to remove aulfate.

${ }^{5}$ Repeat of C.

'Sample was not extracted with chromous acid. 


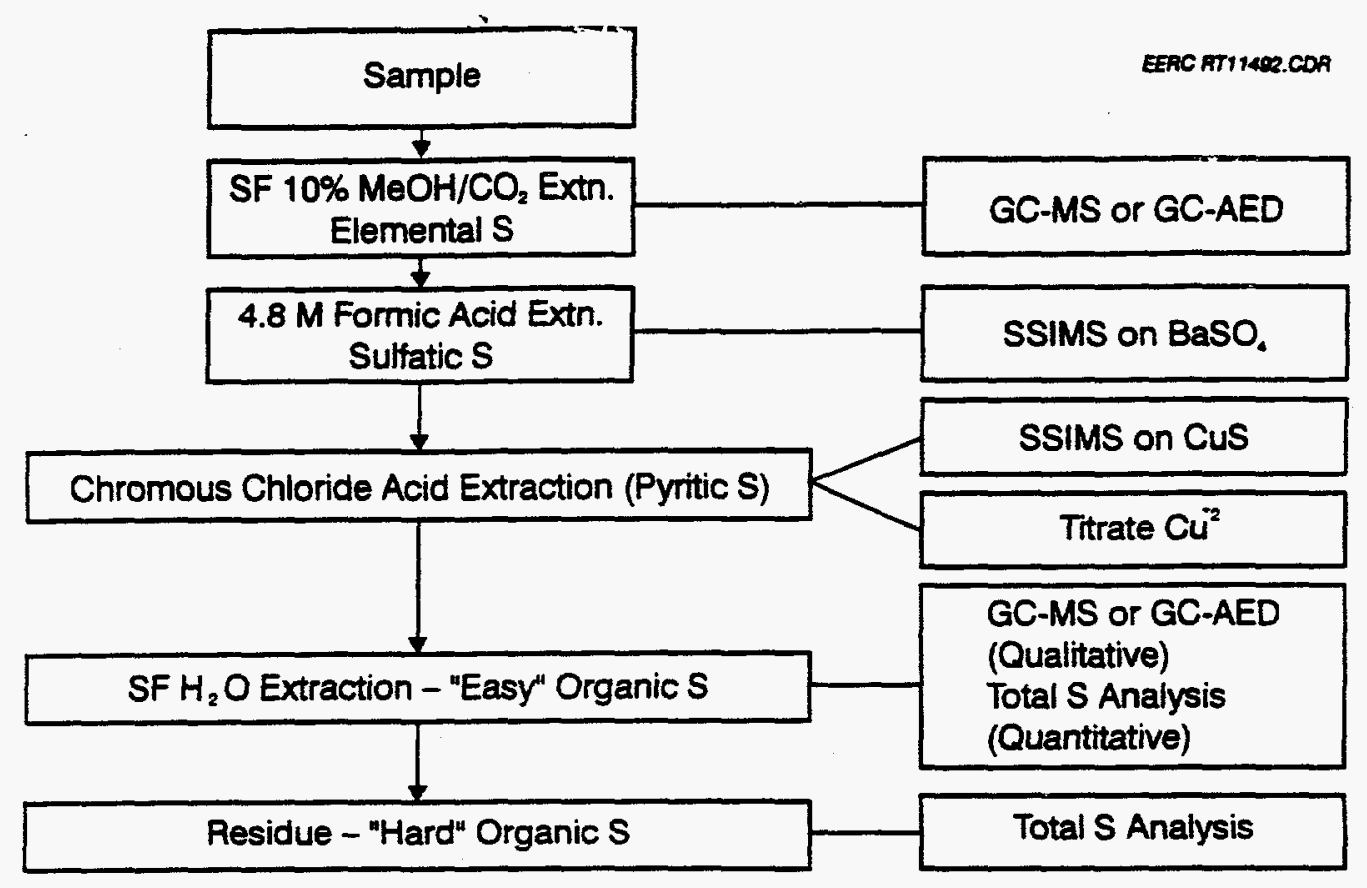

Figure 6. Schematic of extraction techniques for removing sulfur forms from bituminous coals and the analysis techniques used to characterize the extracts and residue.

The sequential steps in extracting and determining the individual sulfur forms is as follows: 1) Elemental sulfur is extracted using supercritical $\mathrm{CO}_{2} / 10 \%$ methanol at $110^{\circ} \mathrm{C}$ for 30 min as described in Publication A. (Note that selective removal of elemental sulfur is necessary, since the ASTM method D2492 incorrectly assigns elemental sulfur to the organic sulfur form.) The quantity of elemental sulfur is directly determined using GC-AED by selectively monitoring the sulfur channel. 2) After extraction of the elemental sulfur, the sulfatic sulfur is selectively extracted using 4.8 $\mathrm{M}$ formic acid in a manner similar to that of the ASTM Method D2492 which utilized $\mathrm{HCl}$ as described in Publication B. (Note that $\mathrm{HCl}$ is not recommended because of the poor sulfur mass balance that results as described earlier in this report.) Sulfate sulfur is then determined using $\mathrm{Ba}^{+2}$ precipitation as in the ASTM Method. 3) Pyritic sulfur is then extracted with chromous acid as described in Publication D. (Note that the ASTM nitric acid extraction is not used because of its nonselective nature for pyritic sulfur and because of the severe changes in the coal matrix that occurs with nitric acid extraction as described earlier in this report.) The pyritic sulfur escapes the reaction vessel as $\mathrm{H}_{2} \mathrm{~S}$ and is trapped as CuS. Ethylenediamine Tetraacetic Acid (EDTA) titration of remaining $\mathrm{Cu}^{+2}$ gives pyritic sulfur concentration. At this point in the extraction scheme, only true organic sulfur is left in the coal. 4) The easy organic sulfur is then extracted with supercritical water at $450^{\circ} \mathrm{C}$ and $400 \mathrm{~atm}$. The amount of easy versus hard organic sulfur before and after supercritical water extraction as described in Publication C. (Note also that pyrolysis-SFE with $\mathrm{CO}_{2} / 10 \%$ methanol at the same conditions could be used to in place of the supercritical water extraction, if desired.) 
Alternate simplified schemes for acquiring only specific information on forms, without performing the complete analysis of the forms, are as follows:

- If $\mathrm{S}_{8}$ is known to be low or is unimportant, SFE with $\mathrm{CO}_{2} / 10 \%$ methanol may be omitted.

- If only $\mathrm{SO}_{4}^{-2}$ is to be determined, only the formic acid extraction is required.

- If only pyritic sulfur is to be determined, only the Canfield extraction is required.

- If $\mathrm{SO}_{4}^{-2}$, pyrite, and total organic are to be determined, SFE with water may be omitted.

\subsection{Additional Information Regarding This Study}

Four papers (A, B, C, and D) describing significant aspects of this work were published in Fuel in the past two years and are referenced in Section 7.0. These papers, along with three presentations (E, F, G), provided concise but thorough discussions of the techniques used and the data obtained from this study. Additional analyses were performed on selected extracts to determine mercury $(\mathrm{Hg})$, selenium ( $\mathrm{Se}$ ), and arsenic (As) content, and the results were presented at an Engineering Foundation Conference in Santa Barbara, CA, in January, 1995 (H).

\subsection{CONCLUSIONS}

- Elemental sulfur is quantitatively extracted from coal by supercritical $\mathrm{CO}_{2} / 10 \%$ methanol at $110^{\circ} \mathrm{C}$ and $400 \mathrm{~atm}$ in $30 \mathrm{~min}$.

- Contrary to popular belief, elemental sulfur correlates with inorganic, not organic sulfur. ASTM Method D2492 errs by including elemental sulfur with organic sulfur, rather than inorganic sulfur.

- Formic acid is more selective than $\mathrm{HCl}$ toward sulfate removal from coal. Including formic acid in the analytical scheme for sulfur forms analysis results in better sulfur mass balance.

- The supercritical fluid extraction of elemental sulfur and the formic acid extraction of sulfate from coal can easily be included with the ASTM D2492 sulfur forms analysis to provide greater sulfur selectivity and, thus, more accurate data on the distribution of sulfur.

- Pyritic sulfur can be removed from coal using the ASTM D2492 $\mathrm{HNO}_{3}$ method or by the Canfield (chromous acid) method for quantitation. However, the Canfield method does not alter the coal matrix, while $\mathrm{HNO}_{3}$ extract significantly alters the coal matrix.

- Two generalized forms of organic sulfur exist in coal. So-called easy organic sulfur is that which is easily removed by supercritical water or by $\mathrm{CO}_{2} / 10 \%$ methanol at $450^{\circ} \mathrm{C}$. Hard organic sulfur is that which remains in the residue following rigorous extraction (supercritical water at $450^{\circ} \mathrm{C}$ and $400 \mathrm{~atm}$ ).

- Supercritical water removes ca. $70 \%$ of the total coal sulfur from raw coal, including sulfatic, pyritic, and organic sulfur, while removing $30 \%$ of the carbon. 
- The ${ }^{34} \mathrm{~S} /{ }^{32} \mathrm{~S}$ isotope ratio tends to be higher in the inorganic (sulfatic and pyritic) sulfur forms than in the organic forms.

- An alternative to the ASTM D2492 method of determining sulfur forms in coal is depicted in Figure 6.

\subsection{REFERENCES}

1. Louie, P.K.K.; Timpe, R.C.; Hawthorne, S.B.; Miller, D.J. Fuel 1993, 72, 225.

2. Annual Book of ASTM Standards, Vol. 05.05, Gaseous Fuels: Coal and Coke, ASTM: Philadelphia, 1991.

3. Louie, P.K.K.; Timpe, R.C.; Hawthome, S.B.; Miller, D.J. "Sulfur Removal from Coal by Analytical-Scale Supercritical Fluid Extraction (SFE) Under Pyrolysis Conditions," Presented at the Coal Utilization and the Environment Meeting, Orlando, FL, May 1993.

4. Canfield, D.E.; Raiswell, R.; Westrich, J.T.; Reaves, C.M.; Berner, R.A. "The Use of Chromium Reduction in the Analysis of Reduced Inorganic Sulfur in Sediments and Shales," Chemical Geology 1986, 54, 149-155.

5. Hawthorne, S.B. "Sulfur Forms in Coal," Final Technical Progress Report, USDOE Cooperative Agreement No. DE-FC21-86MC10637, July 1, 1990 - June 30, 1992.

\subsection{PUBLICATIONS AND PRESENTATIONS REPORTING RESULTS FROM THIS WORK}

A. Louie, P.K.K.; Timpe, R.C.; Hawthorne, S.B.; Miller, D.J. "Determination of Elemental Sulfur in Coal by Supercritical Fluid Extraction and Gas Chromatography with Atomic Emission Detection," Fuel 1993, 72 (2), 225-231.

B. Louie, P.K.K.; Bottrell, S.H.; Timpe, R.C.; Hawthorne, S.B.; Miller, D.J. "An Improved Method For Extracting Sulfate From Bituminous Coals Using Formic Acid," 1994, Accepted for Publication in Fuel.

C. Louie, P.K.K.; Timpe, R.C.; Hawthorne, S.B.; Miller, D.J. "Sulfur Removal from Coal by Analytical-Scale Supercritical Fluid Extraction (SFE) under Pyrolysis Conditions, " Fuel 1994, $73(7), 1173-1178$.

D. Bottrell, S.H.; Louie, P.K.K.; Timpe, R.C.; Hawthorne, S.B. "The Use of Stable Sulfur Isotope Ratio Analysis to Assess Selectivity of Chemical Analyses and Extractions of Forms of Sulfur in Coal," Fuel 1994, 73 (10), 1578-1582.

E. Louie, P.K.K.; Timpe, R.C.; Hawthorne, S.B.; Miller, D.J. "Aspects of Sulfur Removal from Coal by Analytical-Scale Supercritical Fluid Extraction," Seminar presentation at the University of Kentucky, Center for Applied Energy Research, March, 1993. 
F. Hawthorne, S.B.; Louie, P.K.K.; Timpe, R.C.; Miller, D.J.; Bottrell, S.H. "Determination of Sulfur Forms in Coal Using Supercritical Fluid Extraction (SFE), Pyrolysis/SFE, and Acid Digestion/SFE," Presented at the Pittsburgh Conference, Atlanta, GA, March 1993.

G. Louie, P.K.K.; Timpe, R.C.; Hawthome, S.B.; Miller, D.J. "Selective Extraction of Sulfur Forms from Coal by Analytical-Scale Supercritical Fluid Extraction (SFE) and Pyrolysis/SFE," Presented at the 5th International Symposium on Supercritical Fluid Chromatography and Extraction, Baltimore, MD, Jan. 11-14, 1994.

H. Louie, P.K.K.; Timpe, R.C.; Yang, Yu; Miller, D.J.; Hawthorne, S.B. "Precombustion Removal of Selected Hazardous Air Pollutants (HAPs) from Coals with Supercritical Water," Presented at the Economic and Environmental Aspects of Coal Utilization VI - Engineering Foundation Conference, Santa Barbara, CA, Jan. 29 - Feb. 2, 1995. 